\section{Renal nephroblastoma in an adult dog}

\author{
Nefroblastoma renal em cão adulto
}

\author{
Dayane Caicó Collares Araujo** (D), Michel Alves Silva² (D), Cristiano Chaves da Veiga Pessoa ${ }^{3}$ (D) \& \\ Julio Israel Fernandes ${ }^{4}$ (i) \\ 'Veterinary, MSc, Doctorate. Programa de Pós-graduação em Ciências Veterinárias, Universidade Federal Rural do Rio de \\ Janeiro - UFRRJ, Seropédica, RJ, Brasil \\ Veterinary, Dr. Divisão de Prefeitura de Campus, Universidade Federal de São João Del Rei - UFSJ, São João Del Rei, MG, Brasil \\ ${ }^{3}$ Veterinary, Dr. Hospital Veterinário, Instituto de Veterinária, Universidade Federal Rural do Rio de Janeiro - UFRRJ, Seropédica, \\ RJ, Brasil \\ ${ }^{4}$ Veterinary, Dr. Departamento de Medicina e Cirurgia Veterinária, Universidade Federal Rural do Rio de Janeiro - UFRRJ, \\ Seropédica, RJ, Brasil
}

\begin{abstract}
Nephroblastoma is a type of neoplasia originating from the poor differentiation of the metanephrogenic blastema. Neoplasia of embryonic origin, which is commonly reported in dogs less than 2 years old, is rare in adults. Clinical signs include hematuria, polyuria, and palpable abdominal mass. Surgery is elective and chemotherapy depends on the stage of the disease. This paper reports a case of a 6-year-old mixed-breed male canine with a stage I nephroblastoma (according to human staging for Wilms' tumor). The patient performed clinically well and without changes in the staging examinations (i.e., thorax radiographs). The initial complete blood count revealed lymphopenia and no biochemical alterations. Abdominal ultrasound showed a vascularized formation that was cystic with no defined limits and probable origin in the left kidney and a dislocated liver and spleen. The recommended treatment was a total nephrectomy. The kidney was approximately $25.0 \mathrm{~cm}$ in diameter, with an irregular contour, and was covered by a capsule with brown fluid; it did not adhere to adjacent structures. The cut surface had numerous cystic structures. Following a histopathological examination, a nephroblastoma was diagnosed. The patient survived for 33 months without adjuvant chemotherapy.
\end{abstract}

Keywords: embryonic neoplasia, kidney, dogs, surgery.

\section{Resumo}

Nefroblastoma é uma neoplasia originada da má diferenciação do blastema metanéfrico, portanto neoplasia de origem embrionária, que é comumente relatada em cães com menos de dois anos de idade e é rara em adultos. Os sinais clínicos incluem hematúria, poliúria e massa abdominal palpável. A cirurgia é a terapia eletiva e quimioterapia adjuvante depende do estágio da doença. O objetivo deste trabalho é relatar um caso de nefroblastoma em um cão, SRD, de seis anos de idade com nefroblastoma estágio I (de acordo com o estadiamento humano para o tumor de Wilms'). O paciente se apresentou clinicamente bem e sem alterações nos exames de estadiamento (radiografias de tórax). O hemograma inicial indicou apenas linfopenia e perfil bioquímico sem alterações. A ultrassonografia abdominal mostrou formação vascularizada sem limites definidos, cística, com provável origem no rim esquerdo, deslocando fígado e baço. O tratamento recomendado foi nefrectomia total. O rim media cerca de $25,0 \mathrm{~cm}$ de diâmetro, com contorno irregular e era recoberto por uma cápsula com líquido acastanhad, sem aderir a estruturas adjacentes. Na superfície de corte havia numerosas estruturas císticas. O diagnóstico de nefroblastoma foi obtido pelo exame histopatológico. Nenhum tratamento quimioterápico adjuvante foi realizado e até então, o paciente apresenta uma sobrevida de 33 meses.

Palavras-chave: neoplasia embrionária, rim, cães, cirurgia.

\section{BJ $\mathrm{M}$ \\ Brazilian Journal of Veterinary Medicine \\ p-ISSN 0100-2430 \\ e-ISSN 2527-2179 \\ ○}

How to cite: Araujo, D. C. C., Silva, M. A., Pessoa, C. C. V., \& Fernandes, J. I. (2020). Renal nephroblastoma in an adult dog. Brazilian Journal of Veterinary Medicine, 42, e1077820. doi: 10.29374/2527-2179.bjvm107820

Financial support: Coordenação de Aperfeiçoamento de Pessoal de Nível SuperiorBrasil (CAPES).

Conflict of interests: No conflict of interests declared concerning the publication of this article.

Received: September 23, 2019

Accepted: November 11, 2019.

Thestudy was carried out at Hospital Veterinário, Universidade Federal Rural do Rio de Janeiro UFRRJ, Seropédica, RJ, Brasil.

\title{
*Correspondence
}

Dayane Caicó Collares Araujo

Programa de Pós-graduação em Ciências Veterinárias, Universidade Federal Rural do Rio de Janeiro - UFRRJ

Rodovia BR 465, kmO7, s/n, Zona Rural CEP 23890-000 - Seropédica (RJ), Brasil E-mail: dayanecaico@hotmail.com

Copyright Araujo et al. This is an Open Access article distributed under the terms of the Creative Commons Attribution Non-Commercial License which permits unrestricted non-commercial use, distribution, and reproduction in any medium provided the original work is properly cited. 


\section{Introduction}

Nephroblastoma is a rare neoplasm that results from the poor differentiation of the metanephrogenic blastema (Baskin \& De Paoli, 1977). Under normal conditions, the differentiation of the metanephrogenic blastema is induced in the epithelial components, giving rise to nephrons and stromal components that form the connective tissue in the kidney (Brown \& Malik, 2001).

Most reports of canine nephroblastoma have been in animals under 2 years old (Brewer et al., 2011; Montinaro et al., 2013; Michael et al., 2013). It is rare in adult dogs. In humans, nephroblastoma is also known as Wilms' tumor and is the most common renal tumor in children between 6 months and 12 years old (Miniati et al., 2008).

Reported clinical signs are unspecific and include polyuria/polydipsia, vomiting and palpable abdominal mass in 20\% to $43 \%$ of patients, hematuria and, in some patients, weight loss and lethargy (Bryan et al., 2006). The extrarenal occurrence, such as in the spinal cord, is also reported in literature; in these cases, the clinical signs depend on the location of the tumor and frequently include pelvic-limb paresis and ataxia (Gasser et al., 2003; Liebel et al., 2011). Clinical imaging, including excretory urography, ultrasound, and computed tomography, may be useful in diagnosis and surgical planning (Miniati et al., 2008).

Surgery is preferred, especially when the neoplasm affects the kidney; total or partial nephrectomy may be prescribed with or without adjuvant chemotherapy (Bryan et al., 2006). The choice of therapeutic protocol will depend on the stage of the disease and the histopathological features (Kaste et al., 2008). The average lifespan of dogs submitted to surgery without adjuvant treatment is 6 months (Bryan et al., 2006). Given the limited information about this type of neoplasm, this study reports a case of stage I nephroblastoma (according to human staging for Wilms' tumor) with satisfactory survival in an adult dog.

\section{Clinical case}

A 6-year-old mixed-breed uncastrated male canine presented to the Veterinary Hospital of the Federal Rural University of Rio de Janeiro (UFRRJ) in Brazil, with increased abdominal volume that was noticed by the owners 20 days earlier. A mass of firm consistency without definite origins and clinical signs of pain were observed on abdominal palpation. The dog had a normal appetite, water ingestion, urination, and defecation. No alterations of the peripheral lymph nodes were found during palpation.

An abdominal ultrasound showed a vascularized formation with no defined limits and probable origin in the left kidney, and a dislocated liver and spleen (with no changes) (Figure 1). The initial complete blood count revealed lymphopenia; all other indicators were within normal limits (i.e., albumin, urea, creatinine, alkaline phosphatase and aspartate aminotransferase). A chest X-ray image showed no signs of metastasis.

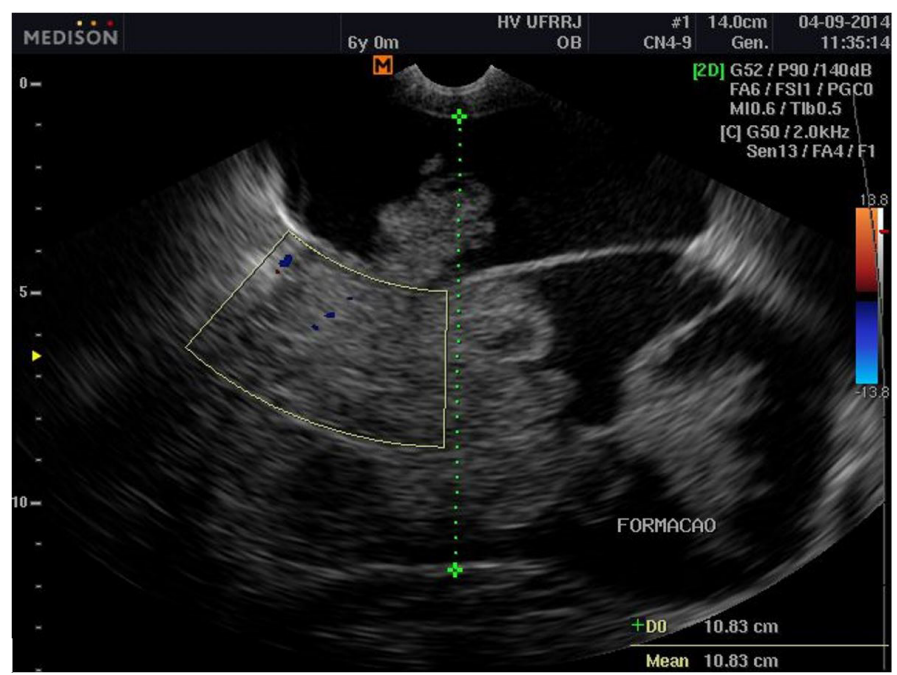

Figure 1. Cystic and vascular formation in the right kidney. 
The recommended treatment was a total nephrectomy. No preoperative medications were prescribed since the surgery was immediately scheduled after diagnosis. Rim media was approximately $25.0 \mathrm{~cm}$ in diameter, and the cut kidney surface had an irregular contour, which was entirely covered with numerous multifocal and coalescent cysts, and a capsule, which was filled with approximately $50 \mathrm{~mL}$ of a brown fluid and did not adhere to the adjacent structures or other abdominal organs (Figure 2). The postoperative treatment consisted of amoxicillin [20 mg.kg-1 PO q 12 h for 10 days], tramadol chloride [3 mg.kg-1 PO q 12 h for 5 days], dipyrone [ $25 \mathrm{mg} \mathrm{kg}^{-1} \mathrm{PO}$ q $8 \mathrm{~h}$ for 5 days], and local bandage with chlorhexidine spray [10 $\mathrm{mg} \cdot \mathrm{mL}^{-1}$.

The tissue was preserved in a 20\% buffered formaldehyde solution and a histopathological examination was carried out. The results showed that the neoplasia consisted of a proliferation of spindle cells (i.e., the stromal component) with ovoid or elongated nuclei arranged in bands, a proliferation of rounded cells with round nuclei, hyperchromatic and scarce cytoplasm (i.e., blastema), and stromal proliferation and formation of irregular tubular structures coated with epithelial cells, which sometimes formed large cysts with areas of necrosis and hemorrhage. The final diagnosis was nephroblastoma.

After surgery, adjuvant chemotherapy treatment was not recommended. The patient continued with follow up, and staging examinations were conducted every 3 months for 1 year, and every 6 months subsequently.

Posterior ultrasonographic examinations revealed a gradual and discreet loss of corticomedullary vascularity, suggesting chronic nephropathy in the remaining kidney. No change was observed on kidney function tests for urea and creatinine levels. Examination of abnormal elements and sedimentation revealed increased urinary density (1.070) and proteinuria $(++)$. Only nutritional management for patients with chronic renal disease was maintained.

The animal has had, until this report, a global lifespan of 33 months. Patient is clinically well and a chronically compensated renal disease remains on biannual follow-ups.

\section{Discussion and conclusions}

Primary renal tumors constitute $0.6 \%$ to $1.7 \%$ of all neoplasms in dogs and are less common than metastatic tumors (Klein et al.,1988). Among neoplasms of cellular origin, epithelial tumors such as cystadenocarcinoma/cystadenoma and renal cell carcinoma are the most prevalent (Inkelmann et al., 2011). Baskin \& De Paoli (1977) observed in a retrospective study that 48 of 8149 canine tumors were primary renal neoplasms (0.6\%), and only two were nephroblastomas. The neoplasm occurrence in our case is a rare one.

According to Montinaro et al. (2013), nephroblastoma is more commonly reported in dogs younger than 1 year. In humans, this neoplasia is among the most common solid tumor in childhood, affecting one in every 10,000 children between 2 years and 4 years of age (Brown \& Malik, 2001). The development of nephroblastoma is not strongly related to environmental factors; it is believed that genetic predisposition, primarily mutations in the WT1 gene (i.e., tumor suppressor), underlies pathogenesis, implying genitourinary abnormalities (Brown \& Malik, 2001). Although less common, as in this report, primary renal nephroblastoma has been reported in adult dogs (Martin et al., 2014).

Clinical signs reported in dogs with renal neoplasms are unspecific and include anorexia, weight loss, polyuria, lethargy, or hematuria (Withrow et al., 2013). Several clinical signs were absent in our patient; this factor may explain why the neoplasm was discreet and only diagnosed when the mass was already palpable but with no signs of pain. Bryan et al. reported palpable abdominal mass as one of the main complaints of tumors (in 20\% of animals). Other reported signs were hematuria, polydipsia or polyuria, inappetence, lethargy, weight loss, pain, vomiting and behavior changes (Martin et al., 2014; Seaman \& Patton, 2003).

An ultrasound examination was used to ascertain the involvement of other abdominal organs, except for the left kidney, which was confirmed at the time of the surgical procedure. Ultrasound can be useful in detecting asymptomatic solid neoplasms and the contrast technique can be used to differentiate between malignant and benign lesions (Tamai et al., 2005).

Treatment was based on the staging and histological type, as recommended by the National Wilms' Tumor Study Group (NWTSG) for human patients (D'Angio et al., 1976). Neoplasms can be classified into one of five stages, based on the clinical progression (Table 1). The tumor in 
Table 1. The staging system for nephroblastoma in humans, developed by the National Wilms' Tumor Study Group (D'Angio et al., 1976).

\begin{tabular}{|c|c|}
\hline Stage I & $\begin{array}{l}\text { Tumor limited to the kidney and is completely excised. Renal capsule is intact. Tumor excised without rupture of the capsule and no } \\
\text { evidence of apparent residual tumor. }\end{array}$ \\
\hline Stage II & $\begin{array}{l}\text { Tumor extends beyond the kidney but is completely removed. Regional extension of tumor, vascular infiltration by the tumor or tumor } \\
\text { thrombi evident, local spillage of tumor contents during biopsy and no evidence of apparent residual tumor. }\end{array}$ \\
\hline Stage III & $\begin{array}{l}\text { Residual nonhematogenous tumor confined to abdomen. Evidence of tumor extension into the hilar or periaortic lymph nodes, diffuse } \\
\text { spillage of the tumor into the peritoneal cavity during excision and evidence of microscopic or gross extension of tumor beyond surgical } \\
\text { margins. Incomplete resection of the tumor due to local infiltration or vital structures. }\end{array}$ \\
\hline Stage IV & Evidence of hematogenous metastasis \\
\hline Stage V & Bilateral renal involvement at diagnosis. \\
\hline \multicolumn{2}{|c|}{$\begin{array}{l}\text { Histopathological classification } \\
\text { Unfavorable histology (i.e., focal or diffuse anaplasia or a sarcomatous component). }\end{array}$} \\
\hline
\end{tabular}

this report was classified as stage I with favorable histology, and was subjected only to surgical treatment. D'Angio et al. (1976) noted that the proposed staging and histological classification were important in determining the prognosis; patients with tumors classified as stage I (i.e., a tumor that is confined to the kidney and fully excised) had a higher life expectancy when treated with surgery and radiotherapy, and there was no difference in those who received adjuvant chemotherapy.

The classification of favorable histology was based on the absence of a component of sarcoma and anaplasia. Microscopy showed stromal and epithelial elements, which can be explained by the differentiation of the metanephrogenic blastema that, in many instances, is partially maintained in nephroblastoma. This finding characterizes the "triphasic" aspect in which nests of blastema are seen in conjunction with areas of epithelial tubules and stroma (Brown \& Malik, 2001). The histological classification is also strongly indicative of prognosis (Kaste et al., 2008).

Limited data exist on the prognosis of dogs with nephroblastoma. In one study, dogs with extrarenal nephroblastoma (string spinel) that underwent surgical treatment and radiotherapy lived for 374 days on average; those receiving average palliative treatment survived only 55 days (Liebel et al., 2011).

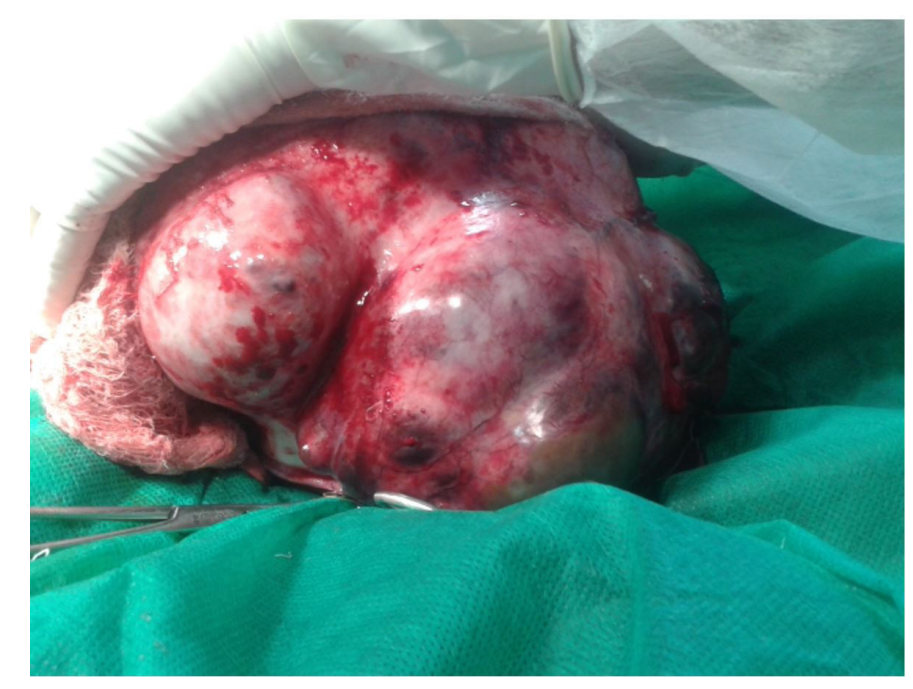

Figure 2. Surgical resection and macroscopic appearance of the right kidney.

Animals with advanced stages of disease, as in humans, have worse prognoses. Martin et al. reported a case of renal nephroblastoma in stage III with unfavorable histology in a dog. The adult dog underwent surgery and adjuvant chemotherapy (vincristine, doxorubicin, and actinomycin D) and lived for only 11 days afterward. Similar to this report, an increased lifespan with better 
prognosis in dogs with initial-stage diseases that were treated surgically with or without adjuvant chemotherapy has been observed (Seaman \& Patton, 2003; Montinaro et al., 2013). In recent decades, the percentage of human patients diagnosed with nephroblastoma who survive for 5-7 years has increased from $30 \%$ to nearly $90 \%$ because of improvements in the staging system, the consequent adaptation of the therapy based on guidelines and advances in diagnostic imaging methods (Kaste et al., 2008).

\section{Acknowledgements}

This study was financed in part by Coordenação de Aperfeiçoamento de Pessoal de Nível Superior-Brasil (CAPES; Brasília, Brazil). The finance code is 001.

\section{References}

Baskin, G. B., \& De Paoli, A. (1977). Primary renal neoplasms of the dog. Veterinary Pathology, 14(6), 591-605. http://dx.doi.org/10.1177/030098587701400606. PMid:201076.

Brewer, D. M., Cerda-Gonzalez, S., Dewey, C. W., Diep, A. N., Van Horne, K., \& McDonough, S. P. (2011). Spinal cord nephroblastoma in dogs: 11 cases (1985-2007). Journal of the American Veterinary Medical Association, 238(5), 618-624. http://dx.doi.org/10.2460/javma.238.5.618. PMid:21355804.

Brown, K. W., \& Malik, K. T. A. (2001). The molecular biology of Wilms' tumour. Expert Reviews in Molecular Medicine, 3(13), 1-16. http://dx.doi.org/10.1017/S1462399401003027. PMid:14987361.

Bryan, J. N., Henry, C. J., Turnquist, S. E., Tyler, J. W., Liptak, J. M., Rizzo, S. A., Sfiligoi, G., Steinberg, S. J., Smith, A. N., \& Jackson, T. (2006). Primary renal neoplasia of dogs. Journal of Veterinary Internal Medicine, 20(5), 1155-1160. http://dx.doi.org/10.1111/j.1939-1676.2006.tb00715.x. PMid:17063709.

D’Angio, G. J., Evans, A. E., Breslow, N., Beckwith, B., Bishop, H., Feigl, P., Goodwin, W., Leape, L. L., Sinks, L. F., Sutow, W., Tefft, M., \& Wolff, J. (1976). The treatment of Wilms' tumor: results of the national Wilms' tumor study. Cancer, 38(2), 633-646. http://dx.doi.org/10.1002/1097-0142(197608)38:2<633::AID-CNCR2820380203>3.0.CO;2-S. PMid:184912.

Gasser, A. M., Bush, W. W., Smith, S., \& Walton, R. (2003). Extradural spinal, bone marrow, and renal nephroblastoma. Journal of the American Animal Hospital Association, 39(1), 80-85. http://dx.doi.org/10.5326/0390080. PMid:12549619.

Inkelmann, M. A., Kommers, G. D., Fighera, R. A., Irigoyen, L. F., Barros, C. S. L., Silveira, I. P., \& Trost, M. E. (2011). Neoplasmas do sistema urinário em 113 cães. Pesquisa Veterinária Brasileira, 31(12), 1102-1107. http://dx.doi. org/10.1590/S0100-736X2011001200011.

Kaste, S. C., Dome, J. S., Babyn, P. S., Graf, N. M., Grundy, P., Godzinski, J., Levitt, G. A., \& Jenkinson, H. (2008) Wilms tumour: prognostic factors, staging, therapy and late effects. Pediatric Radiology, 38(1), 2-17. http:// dx.doi.org/10.1007/s00247-007-0687-7. PMid:18026723.

Klein, M. K., Cockerell, G. L., Harris, C. K., Withrow, S. J., et al.(1988). Canime primary renal neoplasms: a retrospective review of 54 cases. Journal of the American Animal Hospital Association, 24, 443-454.

Liebel, F. X., Rossmeisl Junior, J. H., Lanz, O. I., \& Robertson, J. L. (2011). Canine spinal nephroblastoma: long-term outcomes associated with treatment of 10 cases (1996-2009). Veterinary Surgery, 40(2), 244-252. http://dx.doi. org/10.1111/j.1532-950X.2010.00789.x. PMid:21223320.

Martin, K. D., Sarangom, S. B., Balakrishnan, N. D., Krishna, N. D., et al.(2014). Renal nephroblastoma in an adult dog-a case report. Veterinarski Arhiv, 84, 85-96.

Michael, H. T., Sharkey, L. C., Kovi, R. C., Hart, T. M., Wünschmann, A., \& Manivel, J. C. (2013). Pathology in practice: renal nephroblastoma in a young dog. Journal of the American Veterinary Medical Association, 242(4), 471-473. http://dx.doi.org/10.2460/javma.242.4.471. PMid:23363278.

Miniati, D., Gay, A. N., Parks, K. V., Naik-mathuria, B. J., Hicks, J., Nuchtern, J. G., Cass, D. L., \& Olutoye, O. O. (2008) Imaging accuracy and incidence of Wilms' and non-Wilms' renal tumors in children. Journal of Pediatric Surgery, 43(7), 1301-1307. http://dx.doi.org/10.1016/j.jpedsurg.2008.02.077. PMid:18639686.

Montinaro, V., Boston, S. E., \& Stevens, B. (2013). Renal nephroblastoma in a 3-month-old golden retriever. The Canadian Veterinary Journal, 54(7), 683-686. PMid:24155463.

Seaman, R. L., \& Patton, C. S. (2003). Treatment of renal nephroblastoma in an adult dog. Journal of the American Animal Hospital Association, 39(1), 76-79. http://dx.doi.org/10.5326/0390076. PMid:12549618.

Tamai, H., Takiguchi, Y., Oka, M., Shingaki, N., Enomoto, S., Shiraki, T., Furuta, M., Inoue, I., Iguchi, M., Yanaoka, K., Arii, K., Shimizu, Y., Nakata, H., Shinka, T., Sanke, T., \& Ichinose, M. (2005). Contrast-enhanced ultrasonography in the diagnosis of solid renal tumors. Journal of Ultrasound in Medicine, 24(12), 1635-1640. http://dx.doi. org/10.7863/jum.2005.24.12.1635. PMid:16301719.

Withrow, S. J., Page, R., \& Vail, D. M. (2013). Withrow and MacEwen's small animal clinical oncology (5th ed.). Missouri: Elsevier Health Sciences. 